Doaa Sayed Abdel Azim Mostafa, PhD

\title{
Resisting Borders in Thomas King's "Borders" and Ghassan Kanafani's "Returning to Haifa"
}

\author{
Submitted by \\ Doaa Sayed Abdel Azim Mostafa, PhD \\ Lecturer of English Literature \\ Faculty of Languages \\ October University for Modern Sciences and Arts \\ December 19, 2017
}

\begin{abstract}
The aim of this study is to show one of the major characteristics of resistance literature, which is resisting borders, in two fictional short stories, "Borders" by Thomas King and "Returning to Haifa" by Ghassan Kanafani, discussing how both works have tackled the concept of resisting borders as a form of resistance which the colonized people might apply to confront their colonizers and affirm their identity. The study sheds light on the relationship between settler colonialism and creating borders. Analyzing the two literary texts shows how the physical and psychological borders have come to embody the powerful position of the colonizer and represent a challenge to the colonized Natives. The findings point out that resisting physical borders permits the colonized Natives to affirm their nativism, enter the contact zone with their colonizers, and get rid of many of the psychological barriers which have been made by colonialism. Resisting the physical and psychological borders represents the struggle, which some colonized people have to face to declare their rejection to an unfair situation and rediscover themselves after reconsidering their relation with the colonizers.
\end{abstract}

\section{Introduction}

Ghassan Kanafani was the first literary critic who used the term "resistance literature" in 1966 to refer to the Palestinian literature that tackles and resists the Israeli occupation of Palestine. Kanafani suggests that there is a distinction between the literature written

\section{ELLS Vol.8 No.I (127) December 2017}


Resisting Borders in Thomas King's "Borders" and Ghassan Kanafani's

"Returning to Haifa"

under occupation and that in exile. He declares "No research of this kind can be complete unless the researcher is located within the resistance movement itself inside the occupied land, taking his testimony from the place in which it is born, lives and is propagated: the lips of the people" (qouted in Harlow 3). Harlow argues that the banner of resistance literature is broader than the historical context that Kanafani has tackled, and it may also include all the literatures that grow out of the armed movements that seek independence, becoming more general to be referred to as "Third World Literature" (3). Harlow adds that resistance literature is a political activity, and "it sees itself furthermore as immediately and directly involved in a struggle against ascendant or dominant forms of ideological and cultural production" (28-29).

Moreover, Said, who mentions resistance and opposition as major steps towards decolonization, did not overlook the armed resistance while discussing the cultural resistance. He has classified the periods of resistance into two phases: the period of primary resistance that is represented by "literally fighting against outside intrusion" and then followed by the period of secondary resistance, which is the ideological one, "when efforts are made to reconstitute a shattered community, to save or restore the sense and fact of community against all the pressures of the colonial system" (209). Resistance always begins as a physical armed movement and it is then followed by the ideological cultural resistance in which the natives try to redesign and recover the forms that have been imposed upon them by the colonized. Ashcroft goes further when he stresses the importance of the cultural resistance as it represents a form of saying "no" that is very difficult for imperial powers to combat. He suggests:

\section{ELLS Vol.8 No.I (128) December 2017}


Doaa Sayed Abdel Azim Mostafa, PhD

But the most fascinating feature of postcolonial societies is a 'resistance' that manifests itself as a refusal to be absorbed, a resistance which engages that which is resisted in a different way, taking the array of influences exerted by the dominating power, and altering them into tools for expressing a deeply held sense of identity and cultural being. This has been the most widespread, most influential and most quotidian form of 'resistance' in post-colonial societies. (20)

However, Ashcroft et al. use the term 'post-colonial' to "cover all the culture affected by the imperial process from the moment of colonization to the present day," (The Empire Writes Back 194). While Ashcroft et al. underline the fact that the literary umbrella might be widened to cover the literatures which have been affected by colonialism, and provide an "engagement with all the varied manifestations of colonial power, including those in settler colonies" (The Empire Writes Back 200), LaRocque, the Canadian scholar, criticizes them because "they do not pursue the literary relationship between white colonizer/native colonized" (47). She refers to the perplexed situation of the Native Canadian writers because of the uniqueness of their experience as the native peoples do not have the capability to end their oppression. "Obviously, Native Canadians cannot enjoy fully 'post-coloniality' since their colonial experience is imbricated with the past and present" (LaRocque 48). She adds that as the history of colonization in Canada has continued over a span of 500 years, Native peoples have developed a collective sense of relationship to the land, to each other and to the common cause of decolonization. "In this sense, every politically-aware Native teacher, scholar, writer, artist, filmmaker, poet or activist is ultimately a producer of resistance material" (LaRocque 49).

\section{ELLS Vol.8 No.I (129) December 2017}


In fact, Native Canadians and Palestinians could be categorized as native colonized peoples whose lands have been occupied by invaders and settlers. On one hand, colonialism has banished the Palestinians to be replaced by the Jewish settlers. According to their agreement of Sykes Picot in 1916, Great Britain and France allotted themselves parts of the Ottoman Empire. In 1917, Balfour declaration expressed Britain's support for the creation of a Jewish homeland in Palestine. In 1947 the United Nations declared the partition plan which recommended the creation of independent Arab and Jewish states. Following the partition plan, the Zionists' attacks against Palestinians had intensified. "But, the Arab indigenous population of Palestine could not be indifferent to the presence of the new Jewish settlers. From 1891 and onward, tensions existed between Jewish settlements and Arab residents" (Bassiouni and Ben-Ami 15). Hundreds of thousands of Palestinians were uprooted from their homes leaving Palestine to live in exile, refugee camps, or immigrate while others have remained under the Israeli jurisdiction in the West Bank and Gaza Strip.

On the other hand, in the seventeenth century there was a fierce rivalry between France and England for trading with native Canadians for furs and skins. In 1670 the English founded the Hudson Bay Company which had exclusive rights to trade with the natives. During the Seven Years War (1756-63) Britain and France fought to control Canada. All of the Canadian dependencies were ceded to Great Britain by France in 1763 according to the Treaty of Paris. The French as well as the British ignored the fact that they were not the real owners of the Canadian territories, for there were the Native Canadians- mainly the Inuits and Metis who had been living in Canada before Europeans had even set foot in the country. The Natives who had accepted to cede their lands and sign treaties with the European colonizers were forced to do that.

\section{ELLS Vol.8 No.I (130) December 2017}


But the treaties all derived, ultimately, from the fact of white invasion, which was inherently aggressive. The idea that the Aboriginals desired to cede their lands, imperialism notwithstanding, clearly makes no sense at all unless one embraces a colonial ideology that endorses imperial land theft. Why would anyone freely give up huge regions of traditional territory in return for a degraded status on small areas of marginal land? Aboriginals were compelled by force or the threat of use of force. (Anderson 4)

According to the Eurocentric language that has been used by the white colonizers to underrate the colonized countries, both of the Native Canadians and Palestinians belong to the underprivileged worlds. The terms "The First World," "The Second World," "The Third World," and "The Fourth World" refer to, respectively,

(1) Britain, Europe, and the United States;

(2) the white populations of Canada, Australia, New Zealand, and southern Africa (and, for some theorists, the former Soviet bloc); (3) the technologically developing nations, such as India and those of Africa, Central and South America, and Southeast Asia; and (4) the indigenous populations subjugated by white settlers and governed today by the majority culture that surrounds them, such as Native Americans and aboriginal Australians (and, for some theorists, nonwhite populations

\section{ELLS Vol.8 No.I (131) December 2017}


Resisting Borders in Thomas King's "Borders" and Ghassan Kanafani's

"Returning to Haifa"

who have minority status in "First World"

countries, such as African Americans).

(Tyson 420)

Not only have the Native Canadians and Palestinians faced the stigma of being the citizens of the fourth and third worlds, but they also have to face the claims that they have sold their lands or they had willingly accepted to leave. The Native Canadians and Palestinians have been manipulated by the European colonizers who gave themselves the right to cede the lands of these native nations to other colonizing countries. Like France that had ceded the Canadian territories to England, England had ceded the Palestinian territories to the Jews, and, as a result, new settlers have been transplanted into Palestine and Canada. The Palestinians and Native Canadians faced oppression and marginalization at the hands of the colonizers.

Despite the distance and difference between Israel and Canada, these states are intimately connected in the ways that they construct physical boundaries and use organized violence to carve up territory that does not belong to them, controlling membership in society in both subtle and overt ways. They are also connected through dynamic and energetic resistances to these systems of border enforcement and control, revealing the limits of the repressive regimes in both places. (Barker 335)

The confrontation between the European colonizers and the Native colonized has been mainly manifested in the struggle over the lands that Native inhabitants live on and the invaders occupy.

\section{ELLS Vol.8 No.I (132) December 2017}


The invaders' or colonizers' main aim is to perpetuate their existence on the colonized territories and wipe out the traces of the natives or colonized using various operations that range from militaristic invasion to cultural imperialism. Said stated "Just as none of us is outside or beyond geography, none of us is completely free from the struggle over geography. That struggle is complex and interesting because it is not only about soldiers and cannons but also about ideas, about forms, about images and imaginings" (7).

There is a direct relationship between settler colonialism and creating borders. After the European settlers had colonized the lands of the Natives of Canada and Palestine, they created borders demarcating these colonies. "Settler colonialism ultimately depends on an exclusivist concept of nation based on control and ownership of land and territory that is demarcated by borders"(Walia 6). In fact, Thomas King, the Native Canadian writer, and Ghassan Kanafani, the Palestinian writer, could show resistance in their literary writings reflecting that decolonization begins with resisting physical and psychological borders and false images. Thomas King (1943) is a Canadian novelist, short story-writer, essayist, screenwriter, and a politician. He participated in many protests for the First Nation. Ghassan Kanafani (1936-1972) is a Palestinian writer, journalist, and politician. He departed with his family from Palestine in 1948 to Syria, then Kuwait, and finally to settle down in Beirut. He was assassinated in Beirut in 1972. Both writers have realized that it is a fight over the land and the issues relevant to it such as borders which are considered "the ultimate Achilles' heel of colonialism and imperialism" (Walia 10). In this study, I argue that Thomas King's "Borders" and Ghassan Kanafani's "Returning to Haifa" reflect the question of borders and its relation with the concept of supremacy and sovereignty of the state that has been manipulated by colonialism to perpetuate its hegemonic status on one hand and the physical and psychological resistance of the colonized natives on the other hand. Both writers have portrayed

\section{ELLS Vol.8 No.I (133) December 2017}


Resisting Borders in Thomas King's "Borders" and Ghassan Kanafani's

"Returning to Haifa"

characters that challenge borders as an anti-colonial operation to affirm their nativism. By resisting the physical borders which were established by colonizers, the characters move to the contact zone and become well-empowered to defeat the psychological borders that controlled their psyche for a long period of time.

\section{Resisting Physical Borders}

Resistance emerges as the sole choice that the Natives have to declare their existence. Their resistance which revolves mainly around proving that they are the authentic real owners of the lands that were stolen by the colonizers is embodied by resisting borders.

If there is anything that radically distinguishes the imagination of antiimperialism, it is the primacy of the geographical element. Imperialism after all is an act of geographical violence through which virtually every space in the world is explored, charted, and finally brought under control. For the native, the history of colonial servitude is inaugurated by loss of the locality to the outsider; its geographical identity must thereafter be searched for and somehow restored. Because of the presence of the colonizing outsider, the land is recoverable at first only through the imagination. (Said 225)

\section{ELLS Vol.8 No.I (134) December 2017}


The struggle between the colonizers and colonized is for land. "For a colonized people the most essential value, because the most concrete, is first and foremost the land: the land which will bring them bread and, above all, dignity (Fanon, "The Wretched of the Earth" 34). The colonizers claim that the land has become theirs while the Natives fight to restore it. Therefore, borders have been created to refer to the ownership of the inhabitants of a specific area and location; consequently, there is a direct correlation between the ownership and borders. Borders are always needed to define the nation-state, create order, and give a sense of belonging. Borders which are required to emphasize the geopolitical existence of any nation are understood as lines demarcating territory. Cisneros affirms that "Borders describe what happens when different social worlds confront one another, or when boundaries between worlds are crossed. In this sense, both the physical and the figural border serve multiple functions, drawing lines between "citizen" and "alien" or "us" and "them" (whether in the form of territorial borders or ideological divisions), creating a space for community and for border zone contact"(4).

Borders are also necessary for the practice of othering, which is created by colonizers to keep a wide distance or space between themselves and the colonized Natives. The struggle for land has been symbolized by the borders that have been put to prevent the outsiders or the "others" to cross over or eradicate that space. In other words, borders are essential to the colonizers' hegemony and crossing them is essential for the operation of anti-colonialism by the colonized. For the colonized, the borders that have been done by the colonizers are the real challenge. Crossing borders becomes a means of resistance that the colonized apply to affirm their belonging to their lands.

\section{ELLS Vol.8 No.I (135) December 2017}


Resisting Borders in Thomas King's "Borders" and Ghassan Kanafani's

"Returning to Haifa"

That is why King and Kanafani have portrayed the native characters that endeavor to cross borders and the relationship between crossing borders and affirming identity. Resisting borders becomes an essential part of the protagonists' strife against colonialism. King in his short story "Borders" has referred to the idea of resisting physical borders which are represented by a dividing line between the United States and Canada. In 1846 the US and Britain agreed that the $49^{\text {th }}$ parallel is the boundary between the US and Canada. The $49^{\text {th }}$ parallel led to the dispersal and dislocation of the Native Canadians who consequently lost their land and economic self-reliance.

The Canada-U.S. border was originally imposed on indigenous lands by the colonial powers in North America. Nonetheless, aside from some border skirmishes or disputes in the 19th century, the border was friendly, open, and permeable for the local border residents and other border crossers. This was to change at the beginning of the 21 st century. Instead of the so-called "longest undefended border" the Canada-U.S. border has become a controlled and secured border. (Mayer 13)

The unnamed male narrator of "Borders", who uses flashbacks to tell that story of his family which took place when he was nearly thirteen years old, informs readers about his elder sister, Laetitia, who insisted to leave the Canadian reserve many years ago and move "across the line" to find a job and better living in Salt Lake City in The US (King 131). Laetitia who was brought up in a small town in Alberta can cross the borders easily because her father

$\begin{array}{lllll}\text { ELLS Vol.8 No.I (136) December } 2017 & \end{array}$


is American. So, from the beginning of the novel the borders are introduced as a challenging fact in the life of the narrator's family. Going across the borders is not easy for the natives of the Canadian reserves who believe that the land is theirs and such borders are the creations of the colonizers.

On the one hand indigenous peoples dismiss the Canada-U.S. border as superimposed on their ancestral homelands, yet on the other hand the nation-state is important as an interlocutor to reclaim land. Borders often defy intuitive logic, particularly if they are not geophysical borders such as mountain ranges or rivers. This arbitrariness leaves a person with a puzzled sense of why here is here and there is there, which also holds true for the Canada-U.S. border. (Mayer 14)

That confusion regarding the borders and identity of the Native Canadians or Americans has been shown when the narrator's mother who still lives in the Canadian reserve decides to pay a visit to her daughter in the American Salt Lake City. Here the narrator who accompanies his mother narrates the following dialogue between his mother and the border guard:

"Citizenship?"

"Blackfoot," my mother told him.

"Ma'am?"

"Blackfoot," my mother repeated.

\section{$\begin{array}{lllll}\text { ELLS Vol.8 No.I (137) December } 2017 & \end{array}$}


Resisting Borders in Thomas King's "Borders" and Ghassan Kanafani's

"Returning to Haifa"

"Canadian?"

"Blackfoot" (King 135).

The mother insists to mention her native identity, "Blackfoot," that was before the arrival of the white colonizers, showing how resistance empowers nativism in the face of colonialism. Challenging the rules of borders by the Native mother, who ignores the guard reference to the Canadian citizenship, is her simple trial to resist the demarcation that the white European colonizers made when they imposed the Canadian or American citizenship upon the Natives. She attempts to get rid of the colonizers' impact upon her native community. Tyson affirms that many ex-colonials feel they must assert a native identity "both to avoid being swamped by the Western culture so firmly planted on their soil and to recuperate their national image in their own eyes and in the eyes of others. This attempt to eliminate Western influences, is called nativism or nationalism" (423). Therefore, the mother's nationalism or nativism helps her to reclaim and restore her true identity showing a successful result, specially, when the narrator admits that "pride is a good thing to have" (King 140), although the narrator and his mother were denied to enter the American side first and they go back to the Canadian border.

Once again the narrator and his mother have to stop and answer the same questions at the Canadian borders checkpoint. The border guard repeats the same questions and the mother informs her that she is a "Blackfoot," yet the guard comments "I know and I'd be proud of being Blackfoot if I were Blackfoot. But you have to be American or Canadian" (King 139). The guard who adopts and imposes the policy of the colonizers gives the mother two alternatives, but the true identity is not one of them. Yet the mother did not fall into the trap of the guard and stresses her identity once

ELLS Vol.8 No.I (138) December 2017


more. The two alternatives given by the guard are coming from the world of the dominant powerful colonizers. Thus, the borders help to legitimize the geopolitical and social existence of the colonizers, and resisting borders becomes the fight of the colonized against the colonizer to restore their former denied existence and nationality.

Moreover, Kanafani's short story, "Returning to Haifa", sheds lights on the tragedy of the Palestinians. Through the thirdperson point of view, the readers are informed about Said S. who left his native homeland, Haifa, during 1948 war between the Arabs and Israelis and returns to visit it after 1967 war under the Israeli occupation. Said with his wife Safiyya have to cross the borders between what was formerly the Jordanian West Bank and Israel to see his former house and discover what became of their five months old baby, Khaldun, whom they left behind as a result of the chaos and danger caused by the British sudden withdrawal from Palestine and the aggressions of Israelis. While Said and his wife are remembering the killings and escape of the native Palestinians, Said refers to the borders they cross under the Israeli colonialism to go back to Haifa:

You know, for twenty long years I always imagined that the Mandelbaum Gate would be opened some day, but I never, never imagined that it would be opened from the other side. It never entered my mind. So when they were the ones to open it, it seemed to me frightening and absurd and to a great degree humiliating. Maybe I'd be crazy if I told you that doors should always open from one side only, and that if they opened from the other side they must still

\section{ELLS Vol.8 No.I (139) December 2017}


Resisting Borders in Thomas King's "Borders" and Ghassan Kanafani's

"Returning to Haifa"

be considered closed. But nevertheless,

that's the truth. (Kanafani 150)

The protagonist, Said S., underlines the role of the borders represented by the Mandelbaum Gate which has been controlled by the Israeli colonizers to stress their hegemonic position and the inferior "humiliating" situation of the colonized Palestinians. Despite the fact that the Palestinians are the native inhabitants, they should stand behind the gates to get permission from their colonizers to cross borders and visit their homeland. So, Said considers the doors "closed" because they are not the Palestinians' doors or borders. That becomes clear when his wife Safiyya says "I never imagined that I would see Haifa again," Said S. comments "you are not seeing it, They are showing it to you" (Kanafani 151). Here, Said S. points out that what they are watching is directed by the Israeli colonizers and they are the viewers who are supposed to watch what is shown without taking a hand in. Then he elaborates discussing, in detail, the role and significance of the border as a decisive factor in the struggle between the colonizers and colonized:

They opened the border as soon as they completed the occupation, suddenly and immediately. That had never happened in any war in history. You know the terrible thing that happened in April 1948, so now, why this? Just for our sakes alone? No! This is part of the war. They're saying to us, "Help yourselves, look and see how much better we are than you, how much more developed. You should accept being our servants. You should admire us" But you have seen it yourself. Nothing's changed. It was in our

\section{ELLS Vol.8 No.I (140) December 2017}


power to have done much better than they did. (Kanafani 151)

In fact Said S. explicitly explains the relationship between borders and binarism. "Binarism emerges from that tendency of the colonizing thought in general to see the world in terms of binary oppositions that establish a relation of dominance" (Ashcroft et al. "Postcolonial Studies" 19). The Israeli colonizers have also magnified the role of the border to apply that extreme binarism which widens the gap between the heavy-handed Israeli colonizers and the Palestinian colonized and empowers their ability to control the occupied land and the colonized subjects. Not only do the Israeli colonizers want to show their new powerful condition but they also aspire to be admired by the Palestinians, seeking a psychological defeat which is more effective than the physical one.

Resisting physical borders by the narrator's mother who insists that her citizenship or identity is "Blackfoot" in King's "Borders" and Said S. who considers that "the streets names had never changed" (Kanafani 152), is their practical rejection to the existence of the colonizers on their lands and their first step towards decolonization that aims to dismantle the colonialist power in one of its forms- the borders. By crossing borders the protagonists' nativism challenge and refuse the geopolitical map that the colonizers have drawn to legitimize their existence.

\section{Resisting Psychological Borders}

Crossing the physical concrete borders enables the protagonists of "Borders" and "Returning to Haifa" to become face to face with their colonizers as well as the issues they have been trying to suppress for a long period of time. They find themselves in that

\section{ELLS Vol.8 No.I (141) December 2017}


contact zone they have avoided for many years. That contact zone "where disparate cultures meet, clash and grapple with each other, often in highly asymmetrical relations of dominance and subordination" imposes a different struggle with the self rather than with the colonizers (Ashcroft et al. "Postcolonial Studies" 19). In the contact zone each protagonist faces the test of confrontation between his/her world and that of the colonizers which may arouse anxiety. Fanon has affirmed that "contact alone is enough to evoke anxiety" (Black Skin 120). Anxiety is an important experience because it reveals some of the core issues. The characters of both literary works have lived that experience of anxiety which has emerged in the contact zone between the colonizers and the colonized. Anxiety emerges when psychological defense mechanisms momentarily break down. Defense mechanisms are the processes "by which we keep the repressed repressed in order to avoid knowing what we feel we can't handle knowing" (Tyson 15).

In King's "Borders", the narrator says "Laetitia had not left home with my mother's blessing" (King 131), showing how the mother does not welcome her daughter's decision of leaving the reserve. The mother who prefers to keep her daughter with them in the reserve is unconsciously applying avoidance as her psychological defense mechanism. She wants to keep her children and herself away from the direct contact with their colonizers on borders by staying in the reserve and by "staying away from people or situations that are liable to make (her)anxious by stirring up some unconscious - repressed-experience or emotion" (Tyson 15). The mother's repressed emotions are reflected when the narrator informs us how his mother "would stiffen up" (King 133) whenever he was mentioning anything about visiting his sister, Laetitia, in Salt Lake. She represses her worries about facing colonizers. Yet in the contact zone, on borders, with the border guard's questions, she has to

\section{ELLS Vol.8 No.I (142) December 2017}


choose between two hard choices either to mention that she is Canadian and cope with the demands of the colonizer or to mention her true citizenship and identity and bear the consequences. She chooses the second choice. It was the test which the mother was trying to evade facing lest she might fail

The same defense mechanism of avoidance has been applied by Said S. and his wife in Kanafani's "Returning to Haifa". Before they reach their former home in Haifa, the protagonist, Said S. and his wife were talking together. "Now, as they reached the entrance of Haifa, they both fell silent. At that moment they both realized that they had not spoken a word about the matter which had brought them there"(Kanafani 150). Both of Said S. and his wife have avoided any reference to their lost son, Khaldun, whom they left behind during the war of 1984. By reaching Haifa, the contact zone with their colonizers, they have to face the terrible disaster of leaving their child behind under the mercy of their colonizers. So in the contact zone, Said S. feels that the memory he has endeavored to suppress for many years is" coming back full of the same insane turmoil that rightfully belonged only to the actual moments of the experience itself" (Kanafani 156). When he reaches his occupied home in Haifa, he has become anxious by arousing the long suppressed memory of his departure without his child from his home in 1948. Said S. comes back, investigating the home and the new settler and showing that he is the real authentic owner of the house. He also knows that his son whom he left behind was adopted by the Jewish family that has later taken his home.

Thus, both of the narrator's mother in "Borders" and Said S. in "Returning to Haifa" could cross the psychological borders when they have stopped their avoidance to confront their colonizers. That confrontation enables them to get rid of the suppression they applied by avoiding facing their colonizers in the contact zone. According to

\section{ELLS Vol.8 No.I (143) December 2017}


Resisting Borders in Thomas King's "Borders" and Ghassan Kanafani's

"Returning to Haifa"

Freud, the successful psychic therapy needs "first to find the suppression, then to remove the resistance by which this suppression is maintained" (381). Both protagonists suppressed the fact that they avoid any direct contact with their colonizers because of their fears of being defeated by their colonizers if they face them, for they realize that whenever they come into contact with their colonizers "the question of value, of merit arises" (Fanon "Black Skins" 163). Yet, by facing their colonizers and declaring commitment to their native identities, both protagonists could sustain a feeling of personal identity, raise their self- esteem, and eliminate the cause of suppression. The narrator's mother in "Borders" could finally cross over the borders and visit her daughter in Salt Lake City, as a Blackfoot citizen, and Said S. in "Returning to Haifa" could find and face his son, Khaldun, realizing that the Jewish family, Iphrat Koshen, "stole him" (Kanafani 172) as they have stolen the house. According to Fanon, "Man is human only to the extent to which he tries to impose his existence on another man in order to be recognized by him" (Black Skins 168). In fact, both protagonists could impose their existence on their colonizers. The mother could draw attention to her problem, which is considered the tip of the iceberg of many other issues that face the Native Canadians, when the TV covers her story, and finally the border guard allows her to pass wishing her "a pleasant trip" (King 144). Also, Said S. could affirm his existence in the life of his son Khaldun who has almost forgotten the fact that his biological parents are Arabs. Said S. finally declares his pride of the decision of his second son, Khalid, to join the armed resistance of Palestinians "fidayeen," and warns his son, Khaldun, who was named Dov and became a soldier in the Israeli Army, saying " Maybe your first battle will be with a fida'i named Khalid. Khalid is my son" (Kanafani 182).

\section{ELLS Vol.8 No.I (144) December 2017}


By resisting the physical borders then the psychological borders and reaching the contact zone to face the colonizers some facts have been revealed to and about the colonized characters. When Said S. declares, "Yes, sure. We shouldn't have left anything. Not Khaldun, not the house, not Haifa!" (Kanafani 173), he admits his fault when he had left his homeland and did not resist the colonizers. Said S. "felt as if all the walls he'd made himself live inside of for twenty years had shattered, letting him see things clearly" (Kanafani 173). Said could have that introspection to take a final decision regarding Khalid's participation in armed resistance and reconsiders or reevaluates the whole Palestinian experience. $\mathrm{He}$ adds "the greatest crime any human being can commit, whoever he may be, is to believe even for one moment that the weakness and mistakes of others give him the right to exist at their expense and justify his own mistakes and crimes" (Kanafani 186). Here Said S. refutes the claims of the colonizers in general who have provided various justifications for colonizing other nations.

The negative impact of colonialism has been shown in the colonial subjects; "colonized persons who did not resist colonial subjugation" because they have believed in the superiority of the colonizer and their own inferiority (Tyson 421). The colonial subjects have been represented in both literary works by the second generation: Laetitia in "Borders" and Khaldun/ Dov in "Returning to Haifa". On one hand, Laetitia's obsession with the colonizers has been reflected in her fascination with Salt Lake City: the mountains, the temple, the park and the zoo. The narrator tells his impression about his sister's infatuation with the American city, "It was kind of exciting seeing all those color brochures on the table and listening to Laetitia read all about how Salt Lake City was one of the places in the entire world" (King 139). Here Laetitia who has not seen Salt Lake City before believes that it is the best place counting on the images that the American propaganda has created for itself represented by the color brochures. It is also shown in the English

ELLS Vol.8 No.I (145) December 2017


Resisting Borders in Thomas King's "Borders" and Ghassan Kanafani's

"Returning to Haifa"

language she uses in her argument with her mother. The narrator tells the following dialogue: "you can still see the mountain from here" my mother told Laetitia in Blackfoot. "Lots of mountains in Salt Lake" Laetitia told her in English" (King 133). While the mother is committed to her native identity and language, the daughter answers in English reflecting her subjugated personality that is tied to the colonizers' identity and language. Yet, Laetitia, after watching her mother's resistance on borders on the TV, became very proud of her mother and identity. Laetitia could also reconsider her decision about living in Salt Lake after she has stayed there for a period of time. The narrator says " Laetitia said she was thinking about moving back, and Mom told her to do as she pleased, and Laetitia said that she would do" (King 144). So, crossing borders has helped the mother and the daughter to discover the truth about the colonizers and themselves. On the other hand, Khaldon/Dov's commitment to the Israeli occupation and the concepts of colonialism has been shown in his discussion with his father that begins with Khaldun/ Dov's demand "to talk like civilized people" (Kanafani 181). According to Khaldun/ Dov the civilized people, like his Polish Jewish parents, are those who adopt the logic of the western European countries, while the uncivilized colonized people are those who belong to Arab countries like his original or biological parents. Moreover, as he was fostered by a Jewish family, the Iphrats, he adopted their history and ignored his own real history that is associated with the Arab identity. "Colonialism is not satisfied merely with holding a people in its grip and emptying the native's brain of all form and content. By a kind of perverted logic, it turns to the past of the oppressed people, and distorts, disfigures, and destroys it" (Fanon "On National Culture" 238). Khaldun/ Dov says" I went to Jewish school, I studied Hebrew, I go to Temple, I eat Kosher food ... When they told me, I wasn't their own child, it didn't change anything" (Kanafani 181). The Jewish Polish family has stolen the home and son of Said and

ELLS Vol.8 No.I (146) December 2017


deleted Khaldun's past, giving him new name and identity. Khaldun/Dov is very proud of his new culture because he was programmed to see the Arabs as inferior. Said S. raises a rhetorical question" Isn't a human being made up of what's injected into him hour after hour, day after day, year after year?" (Kanafani 183). That question underlines the role that the colonizers play to forge the history and identity of the colonized by writing new history and creating a subjugated identity for the colonized people to control them and perpetuate their own advantageous position. Yet, after that argument Dov "had withdrawn into himself in the chair defeated" and Said thinks "We've lost him, but surely he's lost himself after all this. He will never be the same as he was an hour ago" (Kanafani 183). Thus, that open end in which Said S. declares he has lost his son Khaldun, sheds light upon the defeated Dov, who does not comment. Dov's silence and withdrawal which prove the fragility of his case and personality may lead us to conclude that he may think over in the whole issue in future. Both Kanafani and King could give authentic significant names to their characters such as Khaldun who was born as an Arab and became the Jewish Dov in the colonized territories, Laetitia whose name is common in Quebec, and the narrator's mother whose name is not mentioned in the whole story, emphasizing the fact that such case might be a general issue of many marginalized natives not an individual problem of the narrator's mother or family.

Finally, both of Kanafani and King could apply cultural resistance by creating fictional characters and themes that focus upon the concept of resisting borders. According to Laachir and Talajooy:

We use the concept of "cultural resistance" to describe the way novels, films, plays, and music are used to resist the dominant social, economic,

\section{ELLS Vol.8 No.I (147) December 2017}




\section{Resisting Borders in Thomas King's "Borders" and Ghassan Kanafani's}

"Returning to Haifa"

political, and cultural discourses and structures either consciously or unconsciously. This can be achieved both through the choice of topics, i.e. thematically (breaking of taboos and creating new ways of seeing the past, present and future), and through the developing of new patterns and forms of resistance that defy borderlines by using new forms of language, music, plot, and characters. (5)

In fact Kanfani's "Returning to Haifa" and King's "Borders" could defy borderlines by discussing the issue of borders and the steps of resisting them physically and psychologically through the protagonists of the two fictional works. Resisting the geopolitical borders of the colonizers is a political way of resistance that has been culturally embodied in the two fictional works of Kanafani and King. They could deal with the plot that is built upon the issues of borderlines and create characters that are obsessed with these borders and the authorities that built them.

\section{IV.Conclusion}

One can conclude that resisting borders is a significant feature of resistance literature that has tackled the resistance of the colonized nations to their colonizers. The borders that have been established by the colonizers to demarcate their geopolitical existence on the land of the colonized have represented a challenge to the colonized. In both literary works of King and Kanafani, the colonized protagonists could resist the borders that symbolize the presence of colonialism. While the protagonists resist the physical borders, they unconsciously resist other psychological borders that the colonizers have gradually created to subjugate them as colonized individuals. The protagonists who cross over the physical borders are consequently led to be in the contact zone with their colonizers

ELLS Vol.8 No.I (148) December 2017


and get rid of the avoidance and suppression which they have applied for many years. Being in the contact zone with their colonizers, the colonized protagonists vent their anger and repression and restore their psychological balance; specially, after they could successfully face their persecutors and affirm both their physical existence in the realm of the colonizers and their authentic identity according to their own concepts. Besides, in their experience of resisting borders, the protagonists could live the journey of self-discovery in which they reveal their points of strengths and struggle against the subjugation of the following generations represented by their offspring. While the authors could portray how the protagonists could defeat the borders of the colonizers, they refer to the fact that there are many others who are still being colonial subjects and tied by their fascination with the advantageous image that the colonizers have drawn for themselves. The question of resisting borders is persistent and it may help to create an alternative integrative view to the concept of human liberation as it brings back the lost identities and breaks barriers among human beings.

\section{ELLS Vol.8 No.I (149) December 2017}


Resisting Borders in Thomas King's "Borders" and Ghassan Kanafani's "Returning to Haifa"

\section{Works Cited}

Anderson, Mark Cronlund and Carmen L. Robertson. Seeing Red: A History of Natives in Canadian Newspapers. University of Manitoba Press, 2011. EBSCOhost.

Ashcroft, Bill, et al. The Empire Writes Back: Theory and Practice in Postcolonial Literatures. $2^{\text {nd }}$ ed. Routledge, 2002.

Ashcroft, Bill. Postcolonial Transformation. Routledge, 2001

---Post Colonial Studies: The Key Concepts. $2^{\text {nd }}$ ed. Routledge, 2000.

Baker, Adam J., "No Walls No Borders: Confronting Imperialism and Colonialism in Israel and Canada." Journal of Social, Cultural and Political Protest, vol. 15, no.3, 2016, 335-338.

Bassiouni, M. Cherif and Shlomo Ben Ami. A Guide to Documents on the Arab-Palestinian/Israeli Conflict,1897-2008. Martinus Nijhoff Publishers, 2009.

Cisneros, Josue David. The Border Crossed Us : Rhetorics of Borders, Citizenship, and Latina/O Identity. University Alabama Press, 2014. EBSCOhost.

Fanon, Frantz. The Wretched of the Earth. Translated by Richard Philcox, Grove Press, 1961.

---. Black Skin White Masks. Charles Lam Markmann, Pluto Press, 1986.

\section{ELLS Vol.8 No.I (150) December 2017}


---. "On National Culture." African Intellectual Heritage: A Book of Sources, Temple UP, 1996, pp.236-243.

Freud, Sigmund. A General Introduction to Psychoanalysis. PDF Books World, 2014. Accessed $28 \quad$ May 2017. https://eduardolbm.files.wordpress.com/2014/10/a-general-introductionto-psychoanalysis-sigmund-freud.pdf.

Harlow, Barbara. Resistance Literature. Methuen, 1987.

Kanafani, Ghassan. "Returning to Haifa." Palestine's Children: Returning to Haifa and Other Stories. Trans. Barbara Harlow and Karen E. Riely. Lynne Rienner Publishers, 2000. pp. 149-196.

King, Thomas. "Borders." One Good Story, That One, Harper Collins, 1993. pp.129-46.

Laachir, Karima and Saeed Talajooy. Resistance in Contemporary Middle Eastern Culture: Literature, Cinema, and Music. Routledge, 2013.

LaRocque, Emma. Native Writers Resisting Colonizing Practices in Canadian Historiography and Literature. Dissertation, University of Manitoba, 1999.

Mayer, Evelyn P. Narrating North American Borderlands : Thomas King, Howard F. Mosher and Jim Lynch. Peter Lang Gmbh, Internationaler Verlag der Wissenschaften, 2014. Mainzer Studien Zur Amerikanistik. EBSCOhost. 
Resisting Borders in Thomas King's "Borders" and Ghassan Kanafani's "Returning to Haifa"

Said, Edward W. Culture and Imperialism, Vinatge Books, 1993.

Tyson, Lois. Critical Theory Today: A User-Friendly Guide. $2^{\text {nd }}$ ed. Routledge, 2006.

Walia, Harsha. Undoing Border Imperialism. AK Press. 2013 